\title{
DEVELOPMENT OF THE ACEH COMMUNITY IN JAKARTA BY TAMAN ISKANDAR MUDA (TIM) THROUGH THE UTILIZATION OF MEUNASAH
}

\author{
Umaimah Wahid, and Surya Darma \\ Universitas Budi Luhur, Indonesia \\ Universitas Indonesia, Indonesia \\ umaimah.wahid@budiluhur.ac.id
}

\begin{abstract}
The Aceh Aceh community and its surroundings have been part of the Taman Iskandar Muda (TIM) organization since 1950. TIM has a membership of 265,000 people, forty-seven (47) branches and thirty (30) Meunasahs spread across Jakarta, Bogor, Bekasi, Tangerang, Cilegon, Serang and Kerawang. The TIM developed the Aceh Aceh community by utilizing the meunasah-meunasah in an effort to maintain or reconstruct Aceh's socio-cultural values so as not to disappear. Activities are carried out based on the Outline of the Organization of Taman Iskandar Muda (GBHO-TIM), namely Tahiro Gampong, Tajunjong Nanggroe, Tapakoe Members and Tapeuluah Syedara as the paradigm of community development. Meunasah as a learning center and community center for the people of Aceh Jakarta as follows 1) Silaturrahim, 2) Religious education (recitation of children and adults), 3) Secretariat of Taman Iskandar Muda (TIM) branch. 4) Containment for conflict resolution, 5) Boarding for students and the people of Aceh. 6) Economic and business planning 7) Organizing religious activities. TIM in the last 5 years has utilized the internet network to facilitate the process and communication channels of organizations, both internal and external with the TIM Website, email and using social media facilities such as what'sApp, Facebook, Instagram, while maintaining correspondence.
\end{abstract}

Keywords : Taman Iskandar Muda, Meunasah, Socio-Cultural Reconstruction-Acehnese-Jakarta society

\section{INTRODUCTION}

The organization of Taman Iskandar Muda (TIM) has been officially established since August $24^{\text {th }}, 1950$. This social organization was set up to maintain communication and interaction media. The Aceh community who settled in Jakarta became a friendship need between individuals, especially at the social and communities. The purposes of the TIM are to maintain the cultural values of the Aceh community as the identity of the community, even though they have interacted with other Indonesian communities

The preservation of Aceh's values was developed and preserved by 250,000 Acehnese from 40 branches of the Meunasah (Aceh Traditional Community Center) in Jakarta, Bogor, Bekasi, Tengerang, Banten, Cilegon and Kerawang. Meunasah is not only a place for community gatherings but has been a means of forming and developing the civilization values of the Acehnese people for centuries. The solidarity and harmony of the people of Aceh started from this place. The place is usually owned by each gampong (administrative territorial division in Aceh community).

The meeting place became a basic ideology and strength in the progress of the people of Aceh based on its history. It aims to produce Aceh society with excellences ability, intellectual of intelligence, and professionalism. In the other hand, this basic foothold becomes the basic strength of Aceh's cultural values. Meunasah become a symbol of democracy and power by systematically building Meunasah as the basis of community power. These cultural values can easily control and supervise social, cultural, political and religious aspects

The process of social interaction of community groups were using Meunasah as a place for socialization of various village-village programs so far in Aceh. The function of the Meunasah was to represent the sociocultural symbols of society and religion. The role of communication as social interaction builds family relationships increasingly developing, so that social processes can take place among the social structures of society.

The existence of the meunasah is inseparable in the development of Acehnese society, it is including the people of Aceh, Jakarta and surrounding areas. the Aceh community always built the Meunasah wherever they formed the community. The Aceh community association has been formed since May 26, 1956 and was named Taman Taman Iskandar Muda (TIM). Taman Iskanadar Muda (TIM) has branches in the areas of Bekasi, Bogor, Tangerang, South Tangerang and Cilegon-Serang-Banten. The current number of TIM branches is 40 and almost 90 percent actively manage the organization and socio-cultural needs of the Acehnese people according to their respective domiciles. 
Meunasah represented the learning and community center for the people of Aceh. TIM periodically conducts the formation of the Meunasah to create maximum benefit for the development of the general public and especially the people of Aceh. This has become a part of the process of introducing and deepening the social culture of the local community. Based on the rationale underlying the activities of Taman Iskandar Muda related to the use of Meunasah. The background of the TIM activities was related to the use of the Meunasah. The focus of the problem is: how does the Taman Iskandar Muda (TIM) Meunasah? and the formulation of the problem of this research is: how is the use of Meunasah Taman Iskandar Muda (TIM) maintaining values in the Aceh aceh community?

\section{LITERATURE REVIEW}

Peter L. Berger and Thomas Luckmann wrote their theoretical treatise on popular constructionism with the title Formation of Social Reality in the book of The Social Construction of Reality: A Treatise in the Sociological of Knowledge in 1966. They describe social processes through their actions and interactions when individuals intensely creates a reality that is shared and subjectively shared together. Berger's main thought is that humans and society are continually dialectical, dynamic and plural products. The dialectical process has three stages such as externalization, objectivation and internalization when Berger calls it a moment (Eriyanto, 2002: 14). Extrenalization is an attempt to pour human self-expression into the world in mental and physical activities. This has become a human nature that will always pour themselves into the place where it is located. Objectivation is the achievement of both mental and physical results from human externalization activities. Objective reality as a result can face thought itself as a fact that is outside and different from human nature. Internalization is the absorption of the objective world back into consciousness so that the individual's subjectivity is influenced by the structure of the social world.

The process of social construction takes place by involving social interaction every day. The process requires social communication as part of the social action entity in a society. Social interaction creates a process of communication with dynamic relationships between members and groups, groups with groups or groups with their environment. All social processes link and give meaning while creating new meanings so that social change and social mobility can be realized.

Social communication is a process of communication in the community by involving social systems and processes as well as being an effort to develop and change socially in the community. Every community group has a social system and process. The social systems include all components of social structure which are elements of social statics, while social processes include interaction and communication (social dynamics).

The process of social communication of the Acehnese people took place in Meunasah because this place was an education and community center in the Acehnese community. one of them is the internal strength of the Acehnese people which actually lies in the Meunasah. Meunasah is one of the great concepts of Aceh's education which is expected to capable creating a new civilization power of the Acehnese people. The civilization of the people of Aceh can be restarted from the meunasah as long as it tends to be abandoned by the community. Meunasah is only a place of prayer without maximum use, especially related to the reconstruction process of Acehnese individuals.

In other words, Meunasah is an institution in the Aceh community system, it has a well-established role and rooted in shaping the character of the people of Aceh. Meunasah is the power of the people of Aceh and community entities that if lost will eliminate the identity of the people of Aceh. Therefore, the contribution of meunasah to Aceh civilization is enormous or it can be concluded that the meunasah is the civilization of society itself. Without meunasah, the people of Aceh will lose the character of the Acehnese who have been a force for Aceh.

Aceh's customs and culture are the part of a community system that is deeply embedded in Acehnese society. Studying customs and culture is a philosophical basis for an ethnic group and explain the mindset and behavior that surrounds members of a group or community. The socio-cultural discussion about the customs and culture of the Acehnese people means that it is explaining the interrelationship and integration of culture with the religious values of the people specifically Islam.

Customs are ceremonial habits (ceremonies), ritual behavior, aesthetics (beauty), appreciation of dance, sound art, painting, relief (physical building motifs), clothing and food (ritual and commercial value). Badruzzaman Ismail, Chairperson of the Aceh NAD Province Majlis (Majlis Aada Aceh-MAA) (2002), stated that the resilience of his government at that time was due to his ability to build a culture and structure of the Aceh community. This has become one of the segments of human civilization (civilization of human right). This concept is arranged and formed in philosophical values, narrative maja: Adat ngon hukom lagei zat ngon sifeut (custom and sharia law are two things that cannot be separated) the structure of the implication is concluded in 
Adat like Poe teumeureuhom, law like Syiah Kuala, Kanun like Putroe Phang, Reusam like Lakseumana (honor to the deceased was the late Sultan Iskandar Muda.)

\section{DISCUSSION}

Taman Iskandar Muda (TIM) has its office in the FOBA Dormitory (Jakarta Aceh Student Dormitory), Jl Setiabudi Barat No. 1, South Jakarta. Organizational development is becoming increasingly complex, demanding the need for secretariat facilities and more sophisticated. This organization is growing both in quality and quantity. TIM has 50 branches divided into 7 (seven) Regional Coordinators (Korwil) each 1) Korwil I consists of Balaraja, Banten, Cikupa, Parungpanjang, Kemis-Kutabumi Markets, and Tangerang; 2) Korwil II consists of Ciledug, Grogol, Kebon Jeruk, Kembangan, Pejompongan, Setiabudi-Menteng, and Slipi branches; 3) Korwil III consists of Cempaka Putih-Johar Baru Branch, Kelapa Gading, Matraman, Rawamangun, Senen-Kramat, and Tanjung Priuk; 4) Korwil IV consists of Bekasi Kota Branch, South Bekasi, Cakung, Cikarang, Duren Sawit, and Karawang; 5) Korwil V consists of Bogor, Cibinong, Ciputat, Citeureup, Pasar Minggu, and Tebet Branches; 6) Korwil VI consists of Bojonggede, Kebayoran Baru, Kebayoran Lama-Bintaro, Leuwiliang, Parung, and Serpong-Tangsel Branches; 7) Korwil VII consists of Depok Branch, Depok Sukmajaya, Jatiasih, Jatisampurna, Klender, Pasar Rebo-Kramatjati, and Pondok Gede, Cilegon. Taman Iskandar Muda also manages Aceh-based and Sectoral local-based organizations based on professions and social, cultural and business activities.

To overcome the future, TIM has grown into an organization that is always open to reform management, work programs, vision and orientation, so that this organization becomes quite solid and adequate in a time of change. Even in the last 5 years, the TIM has carried out activities by utilizing internet-communication technology. This can be seen by developing the organization's website and becoming a source of information on the organization's activities both the TIM Center Management and Branch TIM activities. In addition, the TIM has been using internet-based media as website, WA, Facebook, Instagram in the process of correspondence and information sharing and publishing the Taman Iskandara Muda Magazine (INTIM) and other forms of formal letters.

TIM so far has established a basic paradigm for the direction and goals of the organization. These four paradigms comprise the basis for building Aceh and are a concept known as the Outline of the Iskandar Muda Park Organization namely Tahiro Gampong (Maintain or preserve the village), Tajunjong Nanggroe (Honor the State), Tapakoe Member (care the members) and Tapeuluah Syedara (expand relation). The four main missions are still applicable to be carried out today. In the delivery of the four social work paradigms, TIM uses the meunasah as a forum for community development. This place of worship can be used as a foothold and strength in the future development of Acehnese society to produce Acehnese people who have superior abilities and are intellectually and professionally intelligent and have strong Acehnese values.

The process of social interaction of community groups in Aceh so far has used meunasah as a place to socialize various gampong-gampong (villages) programs, even the meunasah is a representation of the socio-cultural symbol of the community that directs all social and even religious activities carried out in this place. The role of communication is essential in the process of social interaction. The important role of the meunasah in the process of socio-cultural construction of the people of Aceh so that the meunasah becomes one of the tools or places that are always built wherever the Acehnese people develop as a community. (PP.TIM 2018 Accountability Report Data).

The people of Aceh are also affected by the penetration of communication technologies such as mass media amid developments and social changes. Various types of mass media have become part of people's lives at all levels of society. The internet creates and grows new media delivery of new information in society. This includes changing conventional media into new media such as Facebook, Twitter, blogs and others. The media divert people as a form of community curiosity about new things and the situation that is developing society. Changing a cultural construction is indeed not easy, both at the level of discourse and practically. This is a representation of the democratic system adopted by the Indonesian people.

\section{The Meunasah Utilization in the Development of the Aceh Community in Jakarta.}

Meunasah is an integral part of the process of civilization for the people of Aceh, specifically for the people of Aceh Jakarta and its surroundings building a meunasah can be a reflection of the development of Acehnese society as well as the development of the Acehnese community in their home regions. Meunasah is a miniature of the social system and is expected to strengthen and maintain the cultural values of Aceh.

The Meunasah has been built by the branch TIM and working independently by the members of the branch TIM. This organization is trying to build a meunasah, although it is not a necessity for every branch to have a 
meunasah. However, this place has become an integral part of the social life of the people of Aceh so that the people of Aceh who settled in Jakarta feel complete with the existence of the meunasah.

The construction of meunasah is not only a matter of maintaining Aceh's social culture. The Aceh community has a longing for the village and meunasah to become a place for the development of Acehnese people in the villages. For the people of Aceh in Jakarta, the meunasah was built because of (historical) experience and a longing for the past. The community now has an office but in the village (village) it does not have an office. The whole community activity empties into meunasah. The place of worship as well as the meeting place became a meeting place, planning activities, resolving conflicts, and also conducted a meunasah.

The meunasah function for the people of Aceh in Jakarta is as follows 1) Silaturrahim (gathering) place, 2) Religious education (recitation of children and adults), 3) Secretariat of Taman Iskandar Muda (TIM) branch. 4) A place for resolving conflicts that arise in the community, and 5) Boarding for students and Acehnese people who have just come from Aceh. The people of Aceh recognize the importance of this place as a symbol of social culture and religious education. Therefore, meunasah is strongly supported to be built even with self-financing from the community. The Acehnese people in Jakarta gained education and childhood experience in Aceh and experienced a period of education at the meunasah, realizing that the meunasah is a place for education as well as a place for friendship among fellow Acehnese people.

In the Aceh community the previous decade, precisely before the reformation, the meunasah was the only place of education for the village community, the center of government, and socio-cultural development. The people of Aceh in Aceh's villages have experienced various changes related to the meunasah. The shape of the building was previously made of wood and has changed in the last 10 years, the building no longer uses wood-based materials entirely.

The role of meunasah has been to build the character of Acehnese with religious, hard (firm), care to help but also open to the changes that have come to encompass their socio-cultural processes so far. Acehnese individuals grow into people who are strong, independent and confident, although this is sometimes understood as a form of stubbornness. This character makes Aceh strong and independent, although the reconstruction process tends to change with changing times.

The people of Aceh in Jakarta are still advised to use the meunasah even though their role may have changed with the role of the meunasah in Aceh's village. The construction of the meunasah is expected to help the young generation who was born in Jakarta and its surroundings be able to get to know the characters and culture of their ancestors. This will preserve the cultural values of the Aceh community in the overseas area.

The TIM seeks to implement modern organizational systems and management in the current years. That is not easy because TIM is a social organization whose existence is more familial and there is no financial benefit system. The focus of the TIM goal is only on the udep and matee (life and death) issues. However, that does not mean that the TIM Organization has not been managed seriously. The team has always tried and managed seriously and even implemented modern management. Seriousness in the management of the TIM was even more focused in the last four periods, the TIM always carried out the mandate of bylaws.

This organization became a modern organization in the period 2012/2016 and 2016/2020. This is indicated by the use of communication technology and social media. This is an effort to understand and follow the dynamics of community organizations that are already highly dependent on communication and information technology. TIM tries to run the organization to its full potential based on service and development of the TIM members towards a better direction. Therefore, the Central TIM and the TIM branch work together to realize the TIM as a modern organization and have the best achievements. Loyalty of members of the organization is created by active participation in various activities

The focus of the Meunasah activity is on the Acehnese community in Jakarta, especially on socio-cultural and religious activities, such as religious studies and Islamic holidays. Besides that, meunasah can also be used by the surrounding community. This was created as a form of implication from the philosophy or paradigm of tapeuluwah syedara (expanding relation) because the people of Aceh in Jakarta and its surroundings are part of the surrounding community where they live. Therefore, meunasah can also be enjoyed and used by other communities so that meunasah as the meeting place or place of worship can be beneficial for the community around meunasahMeunasah is not only a process of reconstruction of the Aceh community, especially in the Aceh village, but also an important place for Aceh's cultural identity. According to the Chairperson of Majeleis Adat Aceh Jakarta (Aceh privileged institution focused on Customary) Prof. Dr. Syamsuddin Machmud, MBA., Stated that meunasah for the people of Aceh is a place and functions as:

1. A place for resolving conflicts and various cases that arise in the community. 
2. Economic planning.

3. Government planning

4. Organizing religious activities such as those used for recitation, commemoration of Islamic holidays and so on.

5. Planning activities down to the fields, to the sea, to the market and so forth.

The conclusion can be determined from the previous statements and findings, this states that the Acehnese and meunasah are part of an institution that is contained in the Acehnese community system. Besides that, the role of he meunasah is essential and strong for the formation of the character of the people of Aceh. Meunasah is a Jasic ornament in the cultural system of the people of Aceh that is able to create Acehnese human resources with sharacter. Meunasah is the power of the people of Aceh so that the identity of the people of Aceh will be lost if here is no place. Therefore, the contribution of the meunasah to the Aceh civilization was enormous and became a civilization of the people themselves. without meunasah the people of Aceh will lose the character of the Acehnese who have been a strength for Aceh.

The people of Aceh overseas living in Jakarta and its surroundings certainly have their respective activities and interests. They also have the desire to maintain friendship with fellow Acehnese people. Maintaining silaturrahmi (relation) for the people of Aceh aims to maintain togetherness, strengthen regional relations with Aceh's cultural values and also plan to build a better future. Therefore, wherever Acehnese live they usually form social organizations such as Taman Iskandar Muda (TIM).

As a social organization took place in metropolitan cities. The TIM is also equipped with tools or selfdevelopment tools such as the internet and social media in daily organizational activities. This effort is carried zut as a form of adaptation to the development of the times with the management of the organization integral to he use of the internet and mass media. Every community organization follows the development of the times in an effort to keep pace with the changing times. Management of modern organizations utilizes the internet, news nedia and social media.

Utilization of internet networks aims to simplify the process and process of organizational communication. Organizational communication processes are needed to form, maintain and create a strong, transparent and sustainable organization. The organizational communication process also determines the success of an organization both internal and external. Utilization of communication technology is one effort to change modern organizations with management and communication systems. The communication process will be faster and zasier between organizations and members or organizations between other institutions

\section{Conclusion}

Based on the research findings and the results of data analysis regarding the patterns of social communication of he Aceh Aceh Community in the TIM Organization, it can be concluded that:

1. Meunasah is a community center that is useful for silaturrahim (relation) activities, religious activities, social activities for the people of Aceh in Jakarta.

2. Taman Iskandar Muda Organization utilizes meunsah in the process of developing and observing Aceh's values in the midst of the Aceh Aceh community in various forms of cooperation and activities with all TIM branches.

3. Taman Iskandar Muda organization has used the internet in managing the organization with the TIM WEBsite, social media and new med

\section{Bibliography}

Berger, Peter, L. and Luckman Thomas, The Social Contruction Of Reality: A Treatise in the Sociology Of Knowledge, New York, 1976.

Bungin, Burhan, Rekonstruksi Sosial Media Massa, Kencana Prenata Media

Group, 2006

২anun Aceh Nomor 5 Tahun 2003 mengenai Pemerintahan Gampong.

Hasjmy, A., Kebudayaan Aceh dalam Sejarah, Penerbit Beuna, 1983.

Ismail, Badruzzaman, Membangun Keistimewaan Aceh Dari Sisi Adat Istiadat, MAA Nanggrou Aceh Darussalam, Banda Aceh, 2007. 
Ismail, Badruzzaman, Fungsi Meunasah Sebagai Lembaga (Hukum) Adat di Aceh Besar, Tesis Magister Hukum, Program Pasca Sarjana Universitas Sumatra Utara, Medan, 2002.

Kurdi, Muliardi, Aceh Di Mata Sejarawan, Rekonstruksi Sejarah Sosial Budaya, LKAS dan Pemerintah Aceh, 2009

Kurniawan. Andri, dalam Artikel "Tugas dan Fungsi Kechiek dan Tuha Peut Dalam Penyelenggaraan Pemerintahan Gampong Lampisang Kecamatan Peukan Banda Aceh Besar Berdasarkan Qanun Nomor 8 Tahun 2004 Tentang Pemerintahan Gampong, Jurnal Dinamika Hukum Volume 10 Nomor 3 September 2012, Fakultas Hukum Universitas Syiah Kuala Banda Aceh.

Nya’ Pha, Hakim, 1998; Hurgronje, 1985; Iskandar Gani, 1998; sebagaimana dituliskan kembali oleh Sulaiman Tripa dalam artikel "Meunasah sebagai Universitas Masyarakat Aceh, Aceh Institute, 5 April 2010.

Soewarno, Meunasah sebagai Universitas Gampong, www.acehinstitute.com, Manday, $5^{\text {th }}$ April 2010

Taman Iskandar Muda, Laporan Pertanggung Jawaban Taman Pengurus 2012-2016 dan Laporan Raker 1 dan 2018.

Tripa, Sulaiman, Artkel “Wawancara Mengenai Buku Meunasah di Gampong Kamoe, dalam surat kabar Waspada. 